\title{
Effect of 24-epibrassinolide on lipoxygenase activity in maize seedlings under cold stress
}

\author{
V. N. Kopich, S. V. Kretynin, O. V. Kharchenko, R. P. Litvinovskaya', N. M. \\ Chashina $^{1}$, V. A.Khripach ${ }^{1}$
}

Institute of Bioorganic Chemistry and Petrochemistry of National Academy of Sciences of Ukraine

1, Murmanska str, Kyiv, Ukraine, 02094;

${ }^{1}$ Institute of Bioorganic Chemistry of National Academy of Sciences of Belarus

5/2, Kuprevich str., Minsk, Bielorus, 220141

kopich@bpci.kiev.ua

\begin{abstract}
Aim. To investigate 24-epibrassinolide influence on the maize seedlings 9- and 13-lipoxygenases activity (9- and 13-LOX) under normal conditions $\left(25^{\circ} \mathrm{C}\right)$ and cold stress $\left(5^{\circ} \mathrm{C}\right)$. Methods. LOX activity was measured after treatment of seedlings with 0.01 and $1 \mathrm{MM}$ 24-epibrassinolide. The enzymes were extracted from maize seedlings with $0.1 \mathrm{M}$ sodium acetate ( $\mathrm{pH} 4.5)$ buffer, supplemented with a non-ionic detergent (0.1\% Brij-99) and EDTA $(0.1 \mathrm{mM})$. The 9- and 13-LOX activities were determined spectrophotometrically at $234 \mathrm{~nm}$ using linoleic acid as substrate at pH 6.0 and 7.0 in the presence or absence of $0.02 \%$ Lubrol PX. Results. 3-6-fold increase in LOX activity of 24-epibrassinolide-treated seedlings was demonstrated under normal conditions. Cold stress in the presence of $1 \mu M$ 24-epibrassinolide enhances the activities of 9-and 13- LOX by 4 and 10 times, respectively. Conclusions. The results obtained enlarge our understanding of possible pathways of LOX metabolites involvement in the formation of cell response to brassinosteroids.
\end{abstract}

Keywords: linoleic acid, lipoxygenase, 24-epibrassinolide, activation, cold stress.

Introduction. Lipoxygenases (EC 1.13.11.12, LOX) are the enzymes that catalyze oxidation of polyunsaturated fatty acids (PUFA) with the 1,4-cis, cis-pentadien system, thus causing] the formation of hydroperoxides of trans-, cis-conjugated dienes [1]. Further enzyme-induced transformations lead to the formation of oxidized derivatives of PUFA, including physiologically active substances - signal compounds, such as jasmonic acid, bactericides and fungicides $[2$,

(C) Institute of Molecular Biology and Genetics NAS of Ukraine, 2010
3]. It has been shown that in vivo stress factors induce activation and change the LOX gene transcript levels [4-7]. Expression of genes of enzymes of LOX-way of PUFA conversion is also modulated by signal molecules (jasmonic, salicylic and abscisic acids) [5, 8-12]. Participation of LOX-signal system in the response of plant cells, induced by brassinosteroids (BRs), was demonstrated in [13]. However, direct influence of BRs on the activity of LOX-way of PUFA metabolism has not been studied yet. Nevertheless, there are some reports indicating that both BRs and 
jasmonic acid stimulate an expression of stress-dependent genes (OPR3, LOX2) [14-16]. So, the connection between the BRs action and the lipoxygenase metabolite level can be suggested.

The present study is aimed to investigate an influence of 24-epibrassinolide on the modulation of maize 9- and 13-LOX activity during the development of plant cell response to the action of cold stress.

Materials and methods. The following chemicals and materials were used: linoleic acid, arachidonic acid, non-ionic detergent Lubrol PX, anionic detergent Brij-99 ("Fluka", Switzerland); ethylenediaminetetraacetic acid (EDTA) ("Reanal", Hungary). All other reactants were of chemical or extra purity. 24-epibrassinolide was synthesized in the Laboratory of Steroid Chemistry of Institute of Bioorganic Chemistry of NAS of Belarus. The biological object was 5-day-growing maize seedlings (Goverla hybrid).

Maize seeds were germinated during 5 days in a thermostat $\left(25^{\circ} \mathrm{C}\right)$ in the dark with supplementation of 0.01 or $1 \mathrm{MM}$ of 24-epibrassinolide or in the absence of this chemical. Some of 5-day seedlings were stayed during $24 \mathrm{~h}$ at $5{ }^{\circ} \mathrm{C}$ for inducing cold stress, others were placed for the same period at $25^{\circ} \mathrm{C}$ (control seedlings). After this the mesocotyls were isolated with a scalpel.

LOX was extracted from mesocotyl tissue [17] with further homogenization in five volumes of $0.1 \mathrm{M}$ sodium acetate buffer ( $\mathrm{pH} 4.5$ ) containing $0.1 \%$ Brij-99, $0.1 \mu \mathrm{M}$ EDTA and $2 \mu \mathrm{mM}$ sodium metabisulfite. After 30-min extraction with stirring, homogenates were centrifugated (45 $\mathrm{min}, 5000 \mathrm{rpm}$ ) in PC-6 centrifuge (Russian Federation). All procedures were performed at $4{ }^{\circ} \mathrm{C}$. The obtained supernatant was used for LOX activity determination. Protein concentration was measured by Bredford method [18].

The reaction mixture for the 9-LOX activity determination in supernatants contained $0.1 \mathrm{M}$ sodium phosphate buffer solution ( $\mathrm{pH}$ 6.0), 0.02\% Lubrol PX, $0.1 \mathrm{mM}$ linoleic acid. The mixture for determination of 13-LOX activity contained $0.1 \mathrm{M}$ sodium phosphate buffer solution ( $\mathrm{pH} 7.0$ ) and $0.02 \mathrm{mM}$ linoleic acid [5, $17,19]$. The reaction was initiated by the adding of 1-2 $\mu \mathrm{g}$ of the enzyme to the mixture and then the enzyme activity was measured with spectrophotometer Specord M-40 ("Carl Zeiss, Jena", Germany) by monitoring the changes in optical density of the reaction mixture in time scale at $\lambda=235 \mathrm{~nm}$.

The results of LOX activity determination have been presented in optical units $(\lambda=235 \mathrm{~nm})$ that corresponds to maximum absorbance of conjugated diene chromophore in a molecule of linoleic acid hydroperoxide (the molar coefficient of extinction is equal to $23000 \mathrm{M}^{-1} \mathrm{~cm}^{-1}$ [20]) in $1 \mathrm{~min}$ per $1 \mathrm{ml}$ of protein solution and in optical units in $1 \mathrm{~min}$ per $1 \mathrm{mg}$ of protein. Measurements were performed in thermostated plates at $25{ }^{\circ} \mathrm{C}$ in three repetitions. Buffer solutions such as $0.1 \mathrm{M}$ sodium acetate $(\mathrm{pH} 4-5) ; 0.1 \mathrm{M}$ MEC-NaOH ( $\mathrm{pH} 5-6.5) ; 0.1 \mathrm{M}$ sodium phosphate ( $\mathrm{pH}$ 6-8); $0.1 \mathrm{M}$ sodium borate ( $\mathrm{pH} 8-9$ ) were used to study $\mathrm{pH}$-dependence of the steady-state rate Vst of linoleic acid oxidation catalyzed by 9-and 13-LOX.

The statistical analysis included calculation of $M \pm$ $m$, where $M$ is a mean value, $m$ is its standard error; number of repetitions $n=3-6$. Mann-Whitney $U$-test was used to compare the group tested. The values of $p<0.05$ were considered statistically significant.

Results and discussion. Optimal conditions for the determination of the 9- and 13-LOX activities have been selected for series of experiments concerning 24-epibrassinolidine effect on the functioning of maize seedling LOX. 9-LOX catalyzes the formation of 9-hydroperoxide, and 13-LOX induces the formation of 13-hydroperoxides of PUFA [17].

LOX activity was studied considering physical and chemical conditions in course of oxidation of linoleic acid since the latter is a substance practically water-insoluble at neutral and acid $\mathrm{pH}$ values. The enzyme activity of various LOX substantially depends on the aggregate state of reaction substrate, $\mathrm{pH}$ of reaction mixture, and the presence of natural or synthetic amphiphilic substances such as phospholipids and detergents [5, 17, 21-25]. Optimal $\mathrm{pH}$ values for action of different LOX can vary from 5.5 to 9.5 . Such wide $\mathrm{pH}$ range conditions unavoidable changes in ionization degree of PUFA and orresponding alteration of their aggregate state from emulsion to true solution [26]. As we previously demonstrated there were two types of LOX. The first type oxidizes predominantly a water-soluble substrate (ionized PUFA in the concentrations significantly lower than critical micelle concentration (CMC)), the 


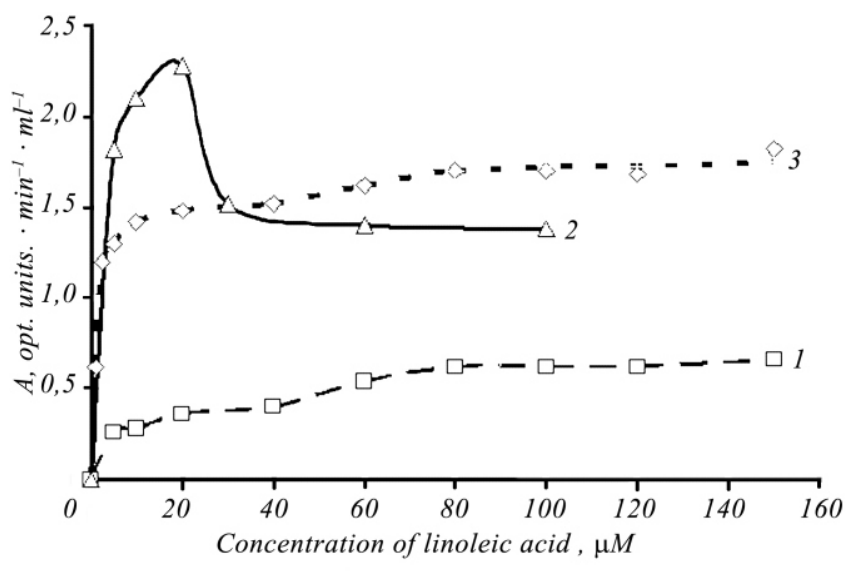

Fig. 1. Dependence of maize seedling 9-LOX $(1,3)$ and 13-LOX (2) activities on linoleic acid concentration :1,2 - intact seedlings; 3 seedlings treated with 24-epibrassinolide $\left(10^{-6} \mathrm{M}\right)$.

second one oxidizes an aggregated form of substrates that are parts of membranes or micelles compositions) [27]. A typical representative of the first class is the soybean 15-LOX (LO-1) that displays enzymatic activity at alkaline $\mathrm{pH}$ and oxidizes the ionized form of substrate in true solution. This enzyme is inhibited with such surface-active compounds as Tween-20, Brij 35, Lubrol PX, Triton X-100, aerosol OT, etc. The similar effect is determined by effective substrate absorbance from the aqueous into micelle phase, not due to the direct interaction between the enzyme and detergent. The example of the second class is 5-LOX from potato tubers, which catalyzes oxidation of non-soluble substrate in the micelle phase formed by Lubrol PX [21-25] and] exhibits maximum activity at $\mathrm{pH}$ 6.3.

To optimize the conditions of functioning of 9-LOX, isolated from maize mesocotyl, we studied dependence of Vst of linoleic acid oxidation on $\mathrm{pH}$ and substrate concentration in the presence of Lubrol PX. The optimal $\mathrm{pH}$ was determined to be 6.0] (data not shown), which is in accordance with the results by other authors [17]. Fig. 1 shows the dependence of 9-LOX activity in maize seedling mesocotyls of intact plants and those treated with $10^{-6} \mathrm{M}$ 24-epibrassilinolide on linolic acid concentration. Difference in Vst values in the range of linoleic acid concentration of $80-150 \mu \mathrm{M}$ did not exceeded $5 \%$. Therefore, further experiments were carried out in the presence of linoleic acid in concentration of $100 \mu \mathrm{M}$ that was considered to be saturating for the enzyme under given conditions. The reaction mixture, containing $0.1 \mathrm{M}$ sodium phosphate buffer solution (pH 6.0), $0.02 \%$ Lubrol PX and $100 \mu \mathrm{M}$ linolic acid, was used in the following experiments to study the effects of 24-epibrassinolide and low temperature on 9-LOX activity.

Taking into account difference between 9- and 13-LOX of maize in their specifity [17], Vst of arachidonic and linoleic acid oxidation were compared. Vst for arachidonic acid was shown to be only $1.53 \pm$ $0.46 \%$ of that for linoleic acid, which is an evidence to the absence of] 13-LOX activity. Maize 13-LOX is known to interact with arachidonic acid as a specific substrate, not only with linoleic acid [17]. The part of water-soluble form of arachidonic acid [at $\mathrm{pH} 6.0$ in the Lubrol PX micelle-containing system is insignificant comparing with the membrane-associated fraction. For that reason, selection of conditions for the 13-LOX activity determination was performed in [the] detergent-free medium to avoid PUFA absorbance and, thus, its removal out of the reaction. The optimal conditions for the oxidation reaction were revealed to be: $\mathrm{pH} 7.0$ (data not shown) and $20 \mu \mathrm{M}$ concentration of linoleic acid in the reaction medium (see curve 2, Fig. 1). Comparative determination of Vst for arachidonic and linoleic acids oxidation under these conditions demonstrated that Vst of arachidonic acid oxidation is $100.8 \pm 10.1 \%$ of that for linoleic acid, which indicates the maize 13-LOX to be activated. Linoleic acid at [the] concentrations more than $20 \mu \mathrm{M}$ considerably inhibits the rate of $13-\mathrm{LOX}$ reaction (curve 2, Fig. 1). This is conditioned by the CMC value for linoleic acid at $\mathrm{pH} 7.0$ exceeding $20 \mu \mathrm{M}$ [19], which results in the linoleic acid micelle formation and the substrate exclusion from the zone of interaction with the enzyme. The reaction mixture, containing $0.1 \mathrm{M}$ sodium phosphate buffer solution ( $\mathrm{pH} 7.0)$ and $20 \mu \mathrm{M}$ linoleic acid, was used for further assessment of activities of 13-LOX, isolated from intact and 24-epibrassinolide-treated maize seedlings as well as from plantlets grown at normal or low temperatures.

The results of investigation of 24-epibrassinolide influence on activities of 9- and 13-LOX, isolated from maize seedling mesocotyls grown under normal conditions and at cold stress, are shown in Fig. 2. Over 

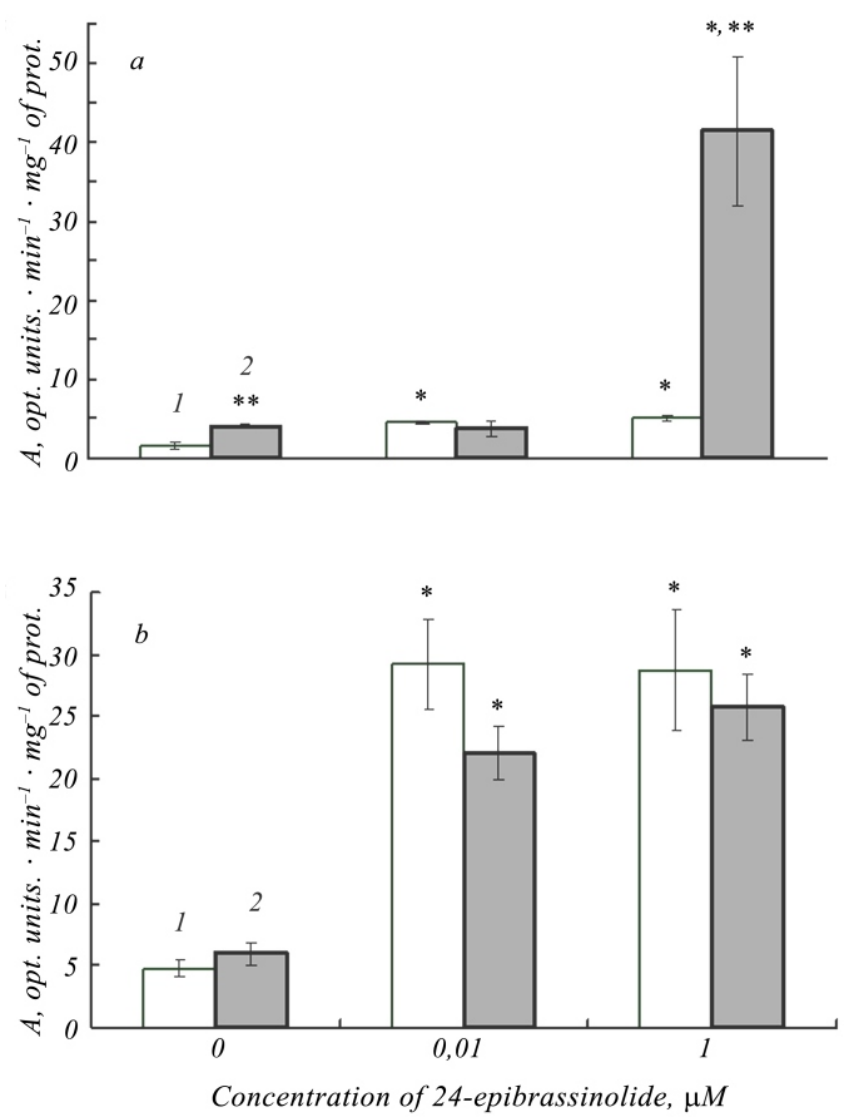

Fig. 2. Influence of 24-epibrassinolide on activities of maize seedling lipoxygenases $(a-13-\mathrm{LOX}, b-9$-LOX) under normal conditions (1) or cold stress (2), $M \pm m(n=3-6)$.

* - statistically significant changes, $\mathrm{p}<0.05$ (at the same temperature: $25^{\circ} \mathrm{C}$ and $5{ }^{\circ} \mathrm{C}$ );

** - statistically significant changes, $p<0.05$ ( at the same concentration of 24-epibrassinolide).

3- and 6-fold increase in mesocotyl LOX activity of the seedlings treated with $10^{-8}$ or $10^{-6} \mathrm{M}$ of 24-epibrassinolide was demonstrated under normal conditions for 13-LOX (Fig. 2, a) and 9-LOX (Fig. 2, b) respectively. Cold stress in the presence of 24-epibrassinolide $\left(10^{-8}\right.$ and $\left.10^{-6} \mathrm{M}\right)$ enhances the activity of 9-LOX by 4 times, whereas the 13-LOX activity increases 10 -fold at $10^{-6} \mathrm{M}$ and no change is observed at $10^{-8} \mathrm{M} 24$-epibrassinolide.

A comparative analysis of the13-LOX activity at 25 and $5{ }^{\circ} \mathrm{C}$ has revealed a joint effect of cold stress and 24-epibrassinolide $\left(10^{-6} \mathrm{M}\right)$ that appeared to be 3 times higher comparing with that at $25{ }^{\circ} \mathrm{C}$. In contrast, cold stress causes less sufficient increase in the 9-LOX activity, by 1.4 times less than that at $25^{\circ} \mathrm{C}$ ). When 24-epibrassinolide action $\left(10^{-6} \mathrm{M}\right)$ at 25 or $5{ }^{\circ} \mathrm{C}$ was compared, it was found that cold stress induced 8 -fold elevation of the13-LOX activity, whereas there were no significant changes in the 9-LOX activity. More pronounced stimulated effect of 24-epibrassinolide on 13-LOX under cold stress points to the intensification of 13-LOX ways of PUFA transformation. Because 13-LOX is a key enzyme of jasmonic acid synthesis, cold stress is thought to increase its level under 24-epibrassinolide influence on the plant cell. 24-epibrassinolide stimulates 9-LOX as well, however, its action appeared to be identical at various temperatures. Our results indicate the involvement of lipoxygenase system in the plant cell response to 24-epibrassinolide influence, in particular, under cold stress condition.

It is known from previous studies that BRs participate not only in the processes of growth and development but also defend plants against various stress factors, i.e. high and low temperatures, drought, high salt concentration, and mechanic injuries $[16,28$, 29]. LOX take part in the adaptation of plants to stress factors as well [4-7]. The products of 9- and 13-LOX (9- and 13-hydroperoxydes of PUFAs) are involved in the enzymatic processes in plant cell[, which lead to the formation of a number of biologically active substances designated as oxylipins $[3,30]$. One of the end products of lipoxygenase cascade is jasmonic acid and its derivatives (jasmonates) [2, 3, 30]. The jasmonates action provides the adaptation of plants to stresses either by direct influence on the activity of several enzymes or indirectly by induction of gene expression [9-12]. The jasmonic acid biosynthesis] is initiated by oxidation of $\alpha$-linoleic acid to 13-hydroperoxide of linoleic acid catalyzed by 13-LOX; 10, 11-reductase of 12-oxophitodienoate acid (OPR) being involved in the cascade of enzymatic reactions $[15,31]$. BRs stimulate the expression of stress-dependent genes OPR3, LOX2 etc. that proves the BRs influence on jasmonic acid synthesis [14-16].

24-epibrassinolide is known to increase the level of lipoxygenase oxidation products, while 4-bromophenacyl bromide, an inhibitor of $\mathrm{A}_{2}$ phospholipase, decreases significantly the level of lipoxygenase metabolites [13]. The authors supposed 
that the oxylipin cell response can occur due to the changes in enzymatic activity (probably resulting from phosphorilation/dephosphorilation of the enzymes or their convertion from proenzyme form), rather than to the alterations in the enzyme biosynthesis induced by 24-epibrassinolide- and 4-bromophenacyl bromide. On the other hand, an effect of lipoxygenase metabolism products, such as 9(Z)-12-hyrdoxy-9-dodecenoic acid (12-HDA) and methyljasmonate, on the plant protein phosphorilation has been established $[32,33]$. Protein phosphorilation under 12-HDA action can indicate the existence of protein kinases directly activated by this acid, as well as to the initiation of assembly of cell signaling systems (adenylatecyclase-, $\mathrm{Ca}^{2+}$, NADP-induced, and probably, "own" lipoxygenase systems). Noteworthy that cold stress induces more than 10-time elevation in phosphorilation level of a protein with molecular mass nearly $15 \mathrm{kDa}$ that is accompanied with the increase in plant frost resistance. [34].

In summary, according to the literature and our own data, 24-epibrassinolide-induced change in the 9and 13-LOX activities evidences to the initiation of the entire complex of cell signal systems, in particular, the LOX-signal system. This can provide realization of the anti-stress program during plant adaptation against harmful environmental conditions. Our results, concerning the involvement of 9- and 13-LOX-ways of PUFA conversion to the forming of cell response on BRs action under cold stress, extend current knowledge on the mechanisms of BRs influence on plant cell at low temperatures.

Conclusions. Influence of 24-epibrassinolide on the activities of 9- and 13-LOX, isolated from maize seedling mesocotyl under normal conditions and cold stress has been investigated. It has been established that 24-epibrassinolide treatment in concentrations of 0.01 or $1.0 \mu \mathrm{M} n$ s induces at normal conditions 3 - or 6-fold increase in the mesocotyl 9- and 13-LOX activities, respectively. Cold stress in the presence of 24-epibrassinolide enhances the activity of 9-LOX by 4 times comparing with control, whereas 10-fold elevation of the 13-LOX activity has been observed as a result of treatment with $1 \mu \mathrm{M} 24$-epibrassinolide. The increase of enzyme activity in response to 24-epibrassinolide addition under cold stress suggests a potential link between the BRs effects and the level of oxidized PUFA derivates, which are formed as products of lipoxygenase reactions.

This study was supported by FRSF of NASU grant № F14/247-2007

В. М. Копіч, С. В. Кретинін, О. В. Харченко, Р. П. Літвіновська, Н. М. Чащина, В. О. Хріпач

Вплив 24-епібрассиноліду на ліпоксигеназну активність у проростках кукурудзи за дії низькотемпературного стресу

Резюме

Мета. Дослідження впливу 24-епібрассиноліду на активність 9- $і$ 13-ліпоксигеназ (9- i 13-ЛОГ) з проростків кукурудзи за нормальних умов $\left(25^{\circ} \mathrm{C}\right)$ та за дї низькотемпературного стреcy $\left(5^{\circ} \mathrm{C}\right)$. Методи. Активність ЛОГ визначали за умов обробки проростків 0,01 i 1 мкM 24-епібрассинолідом. Ферменти екстрагували з проростків кукурудзи в 0,1 М натрій-ацетатному буфері $(\mathrm{pH} 4,5)$ за присутності неіонного детергенту $(0,1$ \% Вrij-99) та ЕДТА (0,1 мМ). Активність 9- і 13-ЛОГвизначали спектрофотометрично при 234 нм з використанням лінолевоі кислоти як субстрату при рН 6,0 і 7,0 за присутності та відсутності 0,02\% Lubrol PX відповідно. Результати. Показано, що за нормальних умов в оброблених 24-епібрассинолідом проростках активність ЛОГ зростає у 3-6 разів. За дії низькотемпературного стресу за присутності 1 мкМ 24-епібрассиноліду активність 9- і 13-ЛОГ підвищувалася в 4 та 10 разів відповідно. Висновки. Одержані в роботі результати розширюють існуючі на сьогодні уявлення щооо можливого шляху залучення метаболітів ЛОГ до формування клітинної відповіді на дію брассиностероїдів.

Ключові слова: лінолева кислота, ліпоксигеназа, 24-епібрассинолід, активація, низькотемпературний стрес.

В. Н. Копич, С. В. Кретинин, О. В. Харченко, Р. П. Литвиновская, Н. М. Чащчина, В. О. Хрипач

Влияние 24-эпибрассинолида на липоксигеназную активность в проростках кукурузы при действии низкотемпературного стресса

Резюме

Цель. Исследование влияния 24-эпибрассинолида на активность 9-и 13-липоксигеназ (9- и 13-ЛОГ) из проростков кукурузы при нормальних условиях $\left(25^{\circ} \mathrm{C}\right)$ и при действии низкотемпературного стресса $\left(5{ }^{\circ} \mathrm{C}\right)$. Методы. Активность ЛОГ измеряли после обработки проростков 0,01 и 1 мкМ 24-эпибрассинолидом. Ферменты экстрагировали из проростков кукурузы в 0,1 М натрий-аиетатном буфере $(\mathrm{pH} \mathrm{4,5)} \mathrm{в} \mathrm{присут-}$ ствии неионного детергента (0,1\% Brij-99) и ЭДТА (0,1 мМ). Активность ЛОГ определяли спектрофотометрически при 234 нм с использованием линолевой кислоты в качестве субстрата (pH 6,0 и 7,0) в присутствии и в отсутствие 0,02\% Lubrol PX соответственно. Результаты. Показано, что в нормальных условиях в обработанных 24-эпибрассинолидом про- 
ростках активность ЛОГвозрастает в 3-6 раз. При действии низкотемпературного стресса в присутствии 1 мкМ 24-эпибрассинолида активность 9- и 13-ЛОГ увеличивается в 4 и 10 раз соответственно. Выводы. Полученные в настоящей работе результаты расширяют существующие на сегодня представления о возможном пути вовлечения метаболитов ЛОГ в формирование клеточного ответа на действие брассиностероидов.

Ключевые слова: линолевая кислота, липоксигеназа, 24эпибрассинолид, активация, низкотемпературный стресс.

\section{REFERENCES}

1. Rokach J. Leukotrienes and Lipoxygenases. Chemical, biological and clinical aspects.-New York: Elsevier, 1989.-518 p.

2. Feussner I., Wasternack C. The lipoxygenase pathway // Annu. Rev. Plant Biol.-2002.-53.-P. 275-297.

3. Grechkin A. N., Tarchevsky I. A. The lipoxygenase signaling system // Russ. J. Plant Physiol.-1999.-46, N 1.-P. 114-123.

4. Lee S. H., Ahn S. J., Im Y. J., Cho K., Chung G. C., Cho B. H., $H a n O$. Differential impact of low temperature on fatty acid unsaturation and lipoxygenase activity in figleaf gourd and cucumber roots // Biochem. Biophys. Res. Communs.2005.-330, N 4.-P. 1194-1198.

5. Nemchenko A., Kunze S., Feussner I., Kolomiets M. Duplicate maize 13-lipoxygenase genes are differentially regulated by circadian rhythm, cold stress, wounding, pathogen infection, and hormonal treatments // J. Exp. Bot.-2006.-57, N 14.P. 3767-3779.

6. Porta H., Rueda-Benitez P., Campos F., Colmenero-Flores J. M., Colorado J. M., Carmona M. J., Covarrubias A. A., Rocha-Sosa M. Analysis of lipoxygenase mRNA accumulation in the common bean (Phaseolus vulgaris L.) during development and under stress conditions // Plant and Cell Physiol.1999.-40, N 8.-P. 850-858.

7. Ben-Hayyim G., Gueta-Dahan Y., Avsian-Kretchmer O., Weichert H., Feussner I. Preferential induction of a 9-lipoxygenase by salt in salt-tolerant cells of Citrus sinensis L. Osbeck // Planta.-2001.-212, N 3.-P. 367-375.

8. Reymond P., Farmer E. E. Jasmonate and salicylate as global signals for defense gene expression // Curr. Opin. Plant Biol.1998.-1, N 5.-P. 404-411.

9. Nishiuchi T., Hamada T., Kodama H., Iba K. Wounding changes the spatial expression pattern of the Arabidopsis plastid $\omega$-3 fatty acid desaturase gene (FAD7) through different signal transduction pathways // Plant Cell.-1997.-9, N 10.P. 1701-1712.

10. Melan M. A., Dong X., Endara M. E., Davis K. R., Ausubel F. M., Peterman T. K. An Arabidopsis thaliana lipoxygenase gene can be induced by pathogens, abscisic acid, and methyl jasmonate // Plant Physiol.-1993.-101, N 2.-P. 441-450.

11. Bell E., Creelman R. A., Mullet J. E. A chloroplast lipoxygenase is required for wound-induced jasmonic acid accumulation in Arabidopsis // Proc. Nat. Acad. Sci. USA.-1995.-92, N 19.-P. 8675-8679.

12. Laudert D., Weiler E. W. Allene oxide synthase: A major control point in Arabidopsis thaliana octadecanoid signalling // Plant J.-1998.-15, N 5.-P. 675-684.
13. Fedina E. O., Karimova F. G., Chechetkin I. R., Tarchevskij I. A., Khripach V. A. The contribution of lipoxygenase metabolism in the brassinosteroid signaling pathway // Dokl. Akad. Nauk. RAN.-2004.-395, N 2.-P. 266-269.

14. Mussig C., Biesgen C., Lisso J., Uwer U., Weiler E. W., Altmann T. A novel stress-inducible 12-oxophytodienoate reductase from Arabidopsis thaliana provides a potential link between brassinosteroid-action and jasmonic-acid synthesis // J. Plant Physiol.-2000.-157, N 2.-P. 143-152.

15. Schaller F., Biesgen C., Mussig C., Altmann T., Weiler E. W. 12-oxophytodienoate reductase 3 (OPR3) is the isoenzyme involved in jasmonate biosynthesis // Planta.-2000.-210, N 6.-P. 979-984.

16. Mussig C., Lisso J., Coll-Garcia D., Altmann T. Molecular analysis of brassinosteroid action // Plant Biol.-2006.-8, N 3.-P. 291-296.

17. Poca E., Rabinovitch-Chable H., Cook-Moreau J., Pages M., Rigaud M. Lipoxygenases from Zea mays L. Purification and physicochemical characteristics // Biochim. Biophys. ActaLipids and Lipid Metabolism.-1990.-1045, N 2.-P. 107114.

18. Bradford M. M. A rapid and sensitive method for the quantitation of microgram quantities of protein utilizing the principle of protein-dye binding // Anal. Biochem.-1976.-72, N 1-2.-P. 248-254.

19. Schilstra M., Veldink G., Vliegenthart J. Effect of nonionic detergents on lipoxygenase catalysis // Lipids.-1994.-29, N 4.-P. 225-231.

20. Gibian M. J., Vandenberg P. Product yield in oxygenation of linoleate by soybean lipoxygenase: The value of the molar extinction coefficient in the spectrophotometric assay // Anal. Biochem.-1987.-163, N 2.-P. 343-349.

21. Butovich I. A., Kharchenko O. V., Naboka Y. N., Kazachkov $M$. G. Characterization of the substrate aggregation state in 5lipoxygenase oxidation of linoleic acid // Ukr. Biokhim. Zh.2001.-73, N 2.-P. 39-43.

22. Kharchenko O. V., Kulinichenko H. I., Butovych I. A. Kinetic mechanisms of linoleic acid oxidation by 5-lipoxygenase from Solanum tuberosum L. // Ukr. Biokhim. Zh.-1999.-71, N 4.-P. 40-44.

23. Kharchenko O. V., Skaterna T. D., Kazachkov M. G., Butovich $I$. A. The role of 4-hydroxy-TEMPO in the reaction of the linoleyl alcohol oxidation by potato tuber 5-lipoxygenase // Biopolym. cell.-2001.-17, N 2.-P. 147-151.

24. Vovk A. I., Kharchenko O. V., Kharitonenko A. I., Kukhar V. P., Babii L. V., Kazachkov M. G., Melnyk A. K., Khilchevsky A. $N$. Hydrophobic nitroxyl radicals inhibit linoleyl alcohol oxidation by 5-lipoxygenase // Russ. J. Bioorg. Chem.2004.-30, N 4.-P. 391-395.

25. Kharchenko O. V., Kharitonenko A. I., Vovk A. I., Kukhar V. P., Babiy L. V., Khilchevskyi A. N., Melnyk A. K. Inhibiting properties of stable nitroxyl radicals in reactions of linoleyl acid and linoleyl alcohol oxidation catalyzed by 5-lipoxygenase // Ukr. Biokhim. Zhur.-2005.-77, N 1.-P. 52-57.

26. Butovich I. A., Tsys' E., V., Mogilevich T. V., Kukhar V. P. The influence of physicochemical factors on linoleic acid oxidation by lipoxygenase // Bioorg. Khim.-1991.-17, N 10.-P. 1273-1280.

27. Butovich I. A., Kharchenko O. V., Babenko V. M. On the interfacial phenomena in lipoxygenase catalysis // Adv. Prostagland. Thromb Leuk. Res.-1995.-23.-P. 159-161.

28. Khripach V., Zhabinskii V., De Groot A. Twenty years of brassinosteroids: Steroidal plant hormones warrant better 
crops for the XXI century // Ann. Bot.-2000.-86, N 3.P. 441-447.

29. Schaller $H$. The role of sterols in plant growth and development // Prog. Lipid Res.-2003.-42, N 3.-P. 163-175.

30. Tarchevsky I. A. Plant Cell Signaling Systems.-M.: Nauka, 2002.-294 p.

31. Farmer E. E., Ryan C. A. Octadecanoid precursors of jasmonic acid activate the synthesis of wound-inducible proteinase inhibitors // Plant Cell.-1992.-4, N 2.-P. 129-134.

32. Karimova F. G., Tarchevsky I. A., Mursalimova N. U., Grechkin A. N. Effect of 12-hydroxydodecenoic acid, a product of the lipoxygenase pathway, on plant protein phosphorylation // Russ. J. Plant Physiol.-1999.-46, N 1.-P. 128-131.
33. Tarchevsky I. A., Karimova F. G., Grechkin A. N., Moukhametchina $N$. $U$. Influence of (9Z)-12-hydroxy-9-dodecenoic acid and methyl jasmonate on plant protein phosphorylation // Biochem. Soc. Transact.-2000.-28, N 6.-P. 870-871.

34. Monroy A. F., Sarhan F., Dhindsa R. S. Cold-induced changes in freezing tolerance, protein phosphorylation, and gene expression: Evidence for a role of calcium // Plant Physiol.1993.-102, N 4.-P. 1227-1235.

UDC 581.19

Received 15.04.09 